\title{
REVIEW
}

\section{Thermal tolerances of sea turtle embryos: current understanding and future directions}

\author{
Robert Howard ${ }^{1}$, Ian Bell ${ }^{2}$, David A. Pike ${ }^{1, *}$ \\ ${ }^{1}$ School of Marine and Tropical Biology, James Cook University, Townsville, Queensland 4811, Australia \\ ${ }^{2}$ Department of Environment and Heritage Protection, Townsville, Queensland 4814, Australia
}

\begin{abstract}
Developing sea turtle embryos only successfully hatch within a relatively narrow temperature range, rendering this immobile life stage vulnerable to the vagaries of climate change. To accurately predict the potential impact of climate change on sea turtle egg mortality, we need to fully understand the thermal tolerance of developing embryos. We reviewed the literature on this topic, and found that published studies interpret the primary literature and subsequent reviews very differently. Based on early literature reviews, the maximum thermal tolerance of sea turtle embryos is frequently cited as either 33 or $35^{\circ} \mathrm{C}$. In many sea turtle populations, however, nest temperatures often exceed $35^{\circ} \mathrm{C}$ by up to several degrees (usually just prior to hatchling emergence) and eggs still hatch successfully. Mean incubation temperatures up to $35^{\circ} \mathrm{C}$ generally produce hatchlings, although leatherback and olive ridley turtle embryos may be less tolerant of high incubation temperatures than green and loggerhead turtle embryos. Sea turtle embryos are likely to be more sensitive to the duration of time spent at potentially stressful temperatures than to the temperature alone. To complicate matters, developing embryos may change their thermal tolerance as they grow. Overall, we are only beginning to understand how exposure to high temperatures experienced in the field influences embryonic development and hatchling production. This knowledge gap is hampering our ability to predict the impacts of climate change on sea turtle populations, and future work should focus on understanding how temperature and other climatic variables influence embryonic development and, thus, crucial population attributes such as hatchling production.
\end{abstract}

KEY WORDS: Climate change $\cdot$ Embryonic development $\cdot$ Hatching success $\cdot$ Lethal thermal limits Marine turtles $\cdot$ Metabolic heating $\cdot$ Thermal mortality $\cdot$ Thermal tolerance

\section{INTRODUCTION}

To successfully adapt to environmental changes, species may be forced to shift their geographic ranges or activity patterns; if this is not possible, they may risk going extinct (Hawkes et al. 2009, Witt et al. 2010, Pike 2013). Given that many physiological functions of ectotherms depend on temperature, the vast majority of terrestrial ectotherms may be vulnerable to climate change (Deutsch et al. 2008, Doody \& Moore 2010). Many ectotherms have a complex life cycle, where the adult and embryonic stages have

${ }^{*}$ Corresponding author: david.pike22@gmail.com different habitat requirements and physiological tolerances to environmental conditions; this vastly complicates the potential impacts of climate change. For example, sea turtles are the most widely distributed reptile taxa (James et al. 2006), and collectively require large areas of oceanic and coastal (both aquatic and terrestrial) habitats for different life stages (Hawkes et al. 2009, Witt et al. 2010). The embryonic stage must occur on land because amniotic eggs need to exchange oxygen through the air for the embryo to develop successfully into a hatchling turtle (Ewert 1985). Unlike the developing embryos of

() The authors 2014. Open Access under Creative Commons by Attribution Licence. Use, distribution and reproduction are unrestricted. Authors and original publication must be credited. 
viviparous species, the immobile egg stage of oviparous species cannot 'behaviourally buffer' itself against environmental changes (Telemeco et al. 2013a, Pike 2014). A warming environment at nest sites may therefore lead to phenological changes in nesting periodicity, altered sex ratios in species with temperature-dependent sex determination, and possible reductions in hatching success (reviewed by Jourdan \& Fuentes in press). Overall, however, the effects of climate change are anticipated to be most dramatic during the egg stage, as opposed to freeliving phases of life history (Hawkes et al. 2009, Pike 2014).

Several reviews have highlighted the climatic threats facing the sea turtle reproductive stage during nesting and egg incubation periods (Hawkes et al. 2009, Poloczanska et al. 2009, Hamann et al. 2013, Pike 2014). Along with water and respiratory gases, temperature plays a crucial role for developing embryos (Mortimer 1990, Segura \& Cajade 2010), and the influence of temperature on sea turtle embryonic development is well-documented (e.g. Mrosovsky 1980, Miller 1985, Ackerman 1997, Wibbels 2003). Even small changes in temperature within the nest environment can have significant consequences for successful hatching, and could directly influence key sea turtle population dynamics (Hewavisenthi \& Parmenter 2002, Wibbels 2003, Poloczanska et al. 2009).

Sea turtle sex is determined during the middle third of embryonic development; a pivotal temperature (generally between $\sim 28$ and $31^{\circ} \mathrm{C}$, depending on the population and species) produces a 1:1 ratio of males to females (Ackerman 1997, Wibbels 2003). At temperatures below pivotal, males are produced, whereas temperatures above pivotal produce proportionately more females (Yntema \& Mrosovsky 1980). A change in temperature as subtle as $0.5^{\circ} \mathrm{C}$ can alter the offspring sex ratio within a clutch from $1: 1$ to 1:0 (Hewavisenthi \& Parmenter 2002). With climate change, increased temperatures within the nest could therefore create a female bias in the primary sex ratio of some sea turtle populations (Hawkes et al. 2009, Fuentes et al. 2010, Telemeco et al. 2013b), which could lead to complete feminisation of hatchlings by 2070 if extreme climate forecasts materialise (Godley et al. 2001, Glen \& Mrosovsky 2004, Hawkes et al. 2007, Fuentes et al. 2010, Laloë et al. 2014). Apart from the effects that elevated temperatures could have on sex ratios, high temperatures can also inhibit successful embryonic development, leading to phenotypic abnormalities or death (Packard et al. 1988, Du \& Ji 2003, Maulany et al. 2012a, Telemeco et al. 2013a, Pike 2014). In freshwater turtles, temperature-related abnormalities disrupt the central nervous system, which can influence hypothalamus development and yolk absorption (Micheli-Campbell et al. 2012). Even if the embryo manages to develop successfully, high temperatures within the nest can reduce oxygen levels and disrupt muscle coordination, inhibiting the ability of sea turtles to ascend to the surface and disperse from the nest after hatching (Matsuzawa et al. 2002, Segura \& Cajade 2010). High incubation temperatures can also produce smallersized hatchlings with reduced locomotor abilities, potentially increasing susceptibility to predation as turtles crawl to the water after emerging from the nest and swim off-shore (Ischer et al. 2009, Segura \& Cajade 2010, Booth \& Evans 2011, Maulany et al. 2012a, Booth et al. 2013, Read et al. 2013, Wood et al. 2014).

In extreme cases, high incubation temperatures result in embryonic mortality, and can decrease hatching success of nests or lead to complete clutch failure (Matsuzawa et al. 2002, Hawkes et al. 2007, Maulany et al. 2012b). Unlike sex-determining temperatures, for which the pivotal range is known in some detail for most sea turtle species (Wibbels 2003), the upper maximal limit to successful incubation is less welldefined. Estimates of both $33^{\circ} \mathrm{C}$ (Miller 1997) and $35^{\circ} \mathrm{C}$ (Ackerman 1997) are frequently cited, but these estimates are based on early studies of natural nest temperatures in the field or artificial incubation experiments at constant temperatures in the laboratory, respectively. The effects of constant and naturally fluctuating temperatures on hatching success and hatchling phenotype can differ substantially (Bowden et al. in press); in some cases, naturally fluctuating thermal regimes can exceed $35^{\circ} \mathrm{C}$, particularly over the last 2 wk of incubation, and still produce hatchings (Hewavisenthi \& Parmenter 2002, Matsuzawa et al. 2002, Ischer et al. 2009, Booth \& Evans 2011, Maulany et al. 2012b, Booth et al. 2013, Read et al. 2013, Wood et al. 2014). Determining the lethal temperature limits to embryonic development is essential to identifying which sea turtle populations are most at risk from embryonic mortality. Here we review the literature to clarify our understanding of how temperature influences sea turtle hatching success and to highlight knowledge gaps that currently limit our ability to predict the impacts of climate change on sea turtle populations. We also briefly discuss some of the potential ways in which sea turtles could adapt to climate change, along with human interventions that could enhance sea turtle population resilience. 


\section{REVIEW OF HIGH-TEMPERATURE INCUBATION STUDIES}

Hendrickson (1958) first documented natural nest temperatures of green sea turtles Chelonia mydas in Malaya and Sarawak; these reached nearly $35^{\circ} \mathrm{C}$ before turtles successfully hatched. A decade later, Bustard \& Greenham (1968) incubated sea turtle eggs in the laboratory under a wide range of constant temperatures, including $15,20,27,32$, and $38^{\circ} \mathrm{C}$. No eggs hatched from the $38^{\circ} \mathrm{C}$ incubation treatment, and hatching success was relatively low $(60 \%)$ at $32^{\circ} \mathrm{C}$ (Bustard \& Greenham 1968). A follow-up study later showed that incubation at both 33 and $35^{\circ} \mathrm{C}$ resulted in $60 \%$ of the eggs hatching (Bustard 1971). Although neither of these early studies provides information on constant temperature incubation between 36 and $37^{\circ} \mathrm{C}$, the results suggest that developing embryos can withstand moderately high temperatures (at least $35^{\circ} \mathrm{C}$ throughout incubation) and still hatch. Bustard (1972) later attempted to narrow down the upper lethal limit by incubating green sea turtle eggs at constant temperatures between 35 and $37^{\circ} \mathrm{C}$, but only mentions 'successful hatching' at these temperatures and does not present quantitative results. In stark contrast to incubating eggs, hatchling sea turtles have been reported to survive temperatures exceeding $40^{\circ} \mathrm{C}$ (Drake \& Spotila 2002). This highlights just how truly vulnerable the egg stage is to extreme temperatures (also see Table 1, Fig. 1).

Although some incubating green sea turtle embryos may be able to withstand temperatures up to $37^{\circ} \mathrm{C}$ for the entire duration of incubation (Bustard 1972), this is not the case for all species (Table 1 , Fig. 1). In loggerhead turtles Caretta caretta (from Merritt Island, Florida, USA), McGehee (1979) found that $71 \%$ of hatchlings emerged when incubated at a constant $32^{\circ} \mathrm{C}$, whereas none emerged at $35^{\circ} \mathrm{C}$. Yntema \& Mrosovsky (1980) also suggested that $35^{\circ} \mathrm{C}$ may represent a lethal limit for loggerhead turtles (from Georgia, USA). Their results revealed a reduction in hatching success with increasing temperature; no eggs hatched at a constant $36^{\circ} \mathrm{C}, 17 \%$ of eggs hatched at $34^{\circ} \mathrm{C}$, and $92 \%$ of eggs hatched at $32^{\circ} \mathrm{C}$ (Yntema \& Mrosovsky 1980). These early studies revealed distinctly higher thermal tolerances of green turtle eggs than loggerhead eggs, at least at constant incubation temperatures. This difference was initially attributed to their tropical and temperate habitat affinities, respectively (McGehee 1979). Later work by Miller \& Limpus (1981) found that only $15 \%$ of green sea turtle eggs from Heron Island, Aus- tralia, hatched when incubated in a constant $33^{\circ} \mathrm{C}$ environment, whereas $100 \%$ of eggs hatched at $29^{\circ} \mathrm{C}$ (Miller \& Limpus 1981). Research on sympatric green and loggerhead turtles from Mon Repos, Australia, also revealed that green and loggerhead eggs failed to hatch when incubated at constant temperatures above $32^{\circ} \mathrm{C}$ (Miller 1982). Together, these early studies make it clear that there is substantial variation among species and populations in the maximum constant incubation temperature at which eggs can successfully hatch (Table 1).

Natural nests in the field, by contrast, can fluctuate on a diel basis, and the mean nest temperature often increases as incubation progresses, due to seasonal temperature changes and from metabolic heat produced by late-stage embryos (Hendrickson 1958, Mrosovsky 1994, Booth \& Astill 2001, Hewavisenthi \& Parmenter 2002, Booth \& Freeman 2006, Maulany et al. 2012a). In the past 10 to $15 \mathrm{yr}$ many studies have found that sea turtle eggs can hatch successfully in natural nests that exceed $35^{\circ} \mathrm{C}$ in the field, although hatching success is substantially reduced above this temperature (Table 1, Fig. 1). Thus, reaching $35^{\circ} \mathrm{C}$ during natural temperature fluctuations is not universally lethal. For leatherback turtles Dermochelys coriacea in Costa Rica, temperatures within hatchery nests can have a mean temperature of $33.6^{\circ} \mathrm{C}$ and reach up to $36.1^{\circ} \mathrm{C}$ without negatively affecting hatching success (Wallace et al. 2004). This finding is not surprising for this species, because the embryos can survive temperatures $>38^{\circ} \mathrm{C}$ towards the end of the incubation period as a result of metabolic heating inside the nest (Binckley et al. 1998). On Ascension Island, green turtle nest temperatures average $32.2^{\circ} \mathrm{C}$, can exceed $35^{\circ} \mathrm{C}$ regularly, and reach maximums up to $36.5^{\circ} \mathrm{C}$, resulting in a moderate hatching success rate of $57 \%$ (Broderick et al. 2001). On Heron Island green turtle nests regularly hatch when nest temperature exceeds $35^{\circ} \mathrm{C}$ late in incubation (Ischer et al. 2009, Booth et al. 2013). In natural loggerhead turtle nests (which constant-temperature laboratory experiments suggest cannot exceed $35^{\circ} \mathrm{C}_{\text {; }}$ Table 1 ), temperatures can reach $35.4^{\circ} \mathrm{C}$ for up to $12 \mathrm{~d}$ during the end of incubation, resulting in $40 \%$ hatching success (Minabe, Japan; Matsuzawa et al. 2002). At the La Roche Percée loggerhead rookery in New Caledonia, nest emergence success can be $>90 \%$ in nests where temperature exceeds $35^{\circ} \mathrm{C}$ for at least $3 \mathrm{~d}$ in a row (Read et al. 2013). In flatback sea turtle Natator depressus nests on Peak Island, Australia, nest temperatures exceeding $35^{\circ} \mathrm{C}$ for $6.5 \mathrm{~d}$ in several nests (maintaining a maximum of $36.5^{\circ} \mathrm{C}$ for $8 \mathrm{~h}$ ) resulted in high hatching success rates, ranging from 84 to 


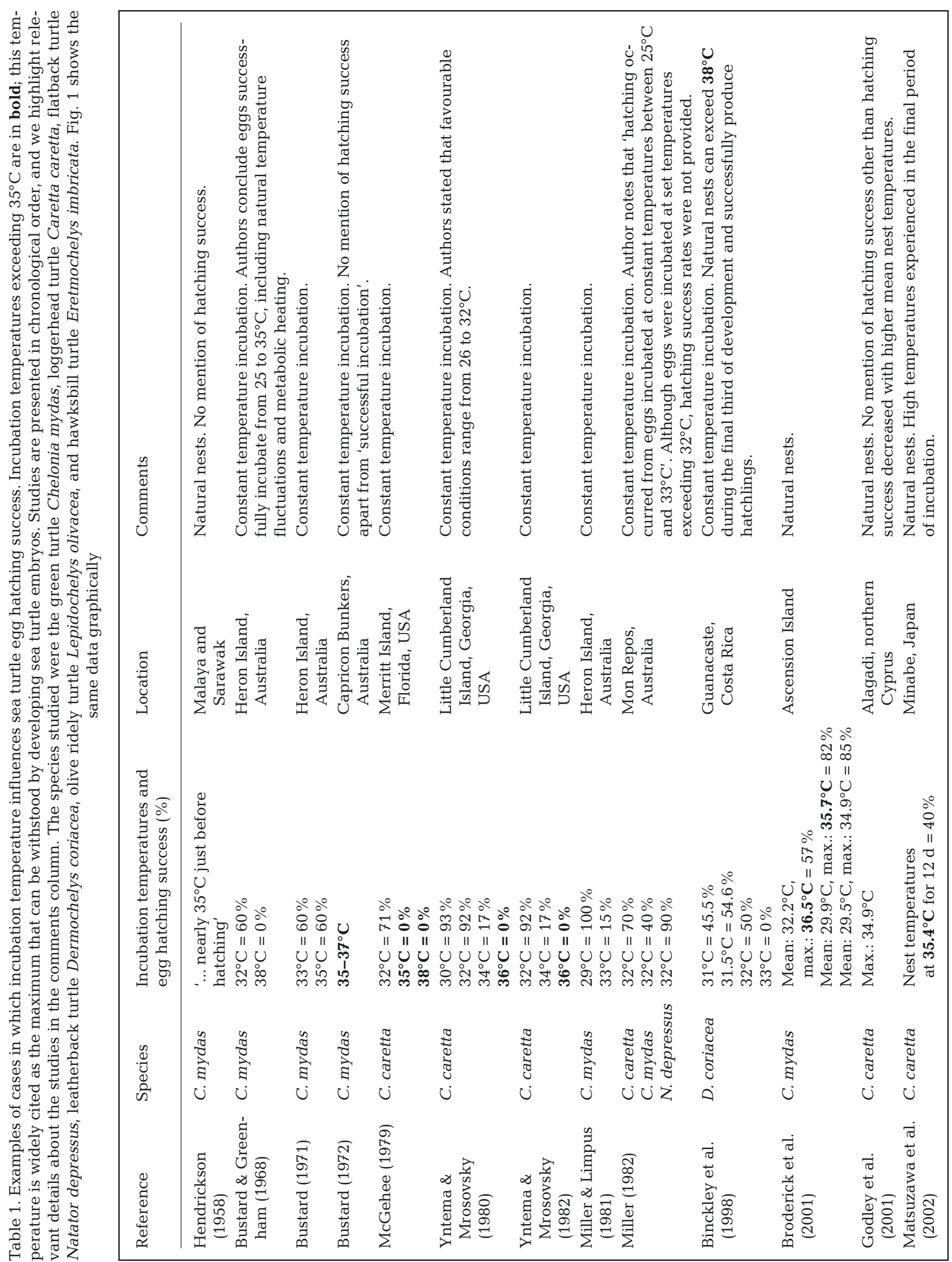




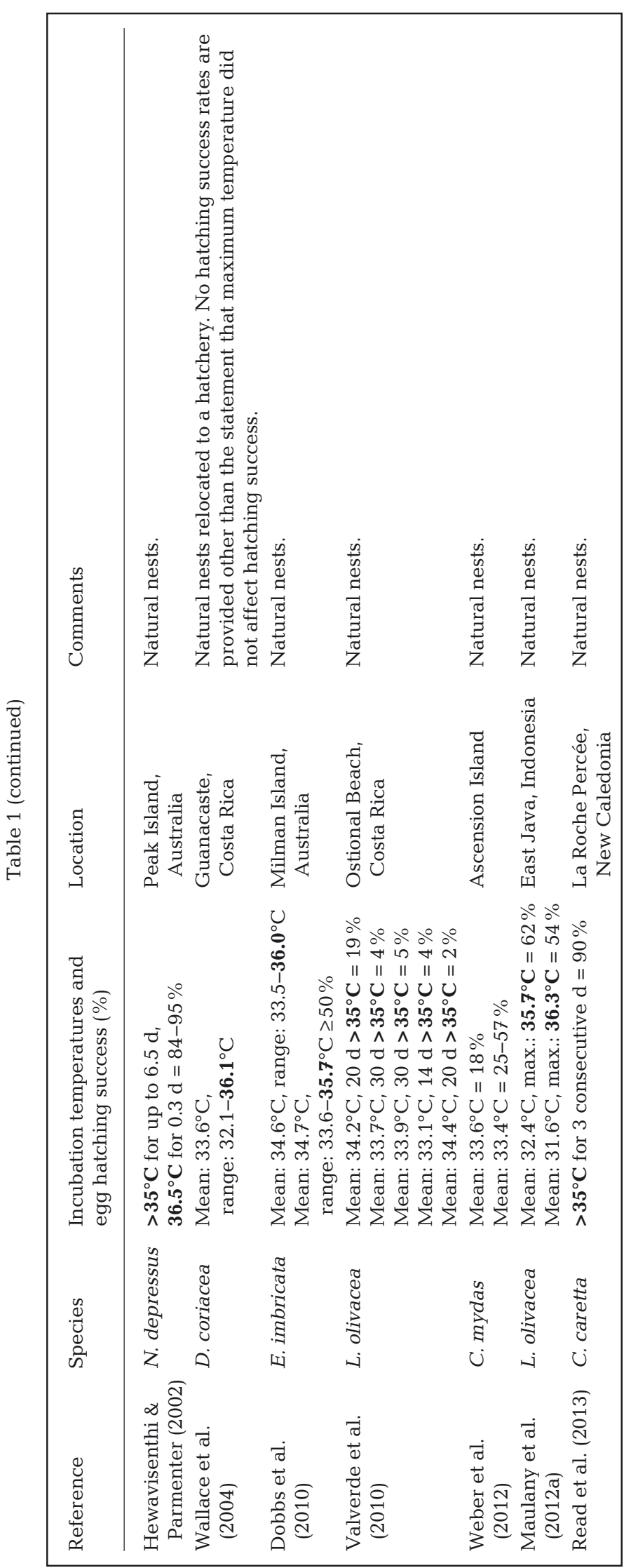

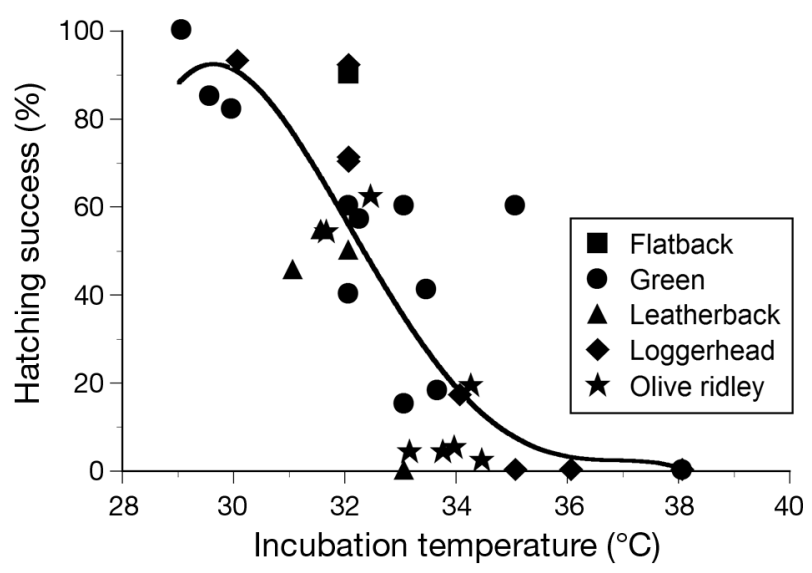

Fig. 1. Relationship between incubation temperature and hatching success for sea turtle eggs, shown by species. We plotted data from studies in Table 1 that incubated eggs under constant or mean temperatures and present quantitative hatching success data. Trend line shows a 4 th order polynomial fit to the entire dataset. Scientific names of species, see Table 1

$95 \%$ (Hewavisenthi \& Parmenter 2002). These data suggest that the lethal limit for this species could be at, or above, $37^{\circ} \mathrm{C}$ near the end of incubation, and that near-term flatback embryos can withstand temperatures exceeding $35^{\circ} \mathrm{C}$ for extended periods. Such high temperatures have also been recorded in hawksbill sea turtle Eretmochelys imbricata nests; at least 1 successful nest averaged $34.6^{\circ} \mathrm{C}$ and ranged from 33.5 to $36.0^{\circ} \mathrm{C}$ (Dobbs et al. 2010).

Studies of incubation temperatures within natural nests provide important information on the temperature range that sea turtle embryos can withstand and at which they can successfully hatch, but have not yet determined whether temperature fluctuation and stage of embryonic development interact, such that the thermal tolerance of embryos changes during incubation. Research on olive ridley sea turtles Lepidochelys olivacea has come closest to answering these questions, by investigating hatching success relative to the duration of time spent above $35^{\circ} \mathrm{C}$. Valverde et al. (2010) found that mean incubation temperatures $>35^{\circ} \mathrm{C}$ on Ostional Beach, Costa Rica, did not produce hatchlings. When the maximum incubation temperatures exceeded $35^{\circ} \mathrm{C}$, the number of days spent above $35^{\circ} \mathrm{C}$ decreased hatching success (with a maximum of $37.13^{\circ} \mathrm{C}$ in the third trimester; Table 1). These results suggest that some of the olive ridley embryos within a clutch can survive temperatures exceeding $37^{\circ} \mathrm{C}$ for short periods, if the mean temperature for the whole incubation period is below $35^{\circ} \mathrm{C}$. 
Olive ridley nests in hatcheries in East Java, Indonesia, show a similar pattern (Maulany et al. $2012 \mathrm{a}, \mathrm{b})$. Nests that reached a maximum of $35.7^{\circ} \mathrm{C}$, but averaged $32.4^{\circ} \mathrm{C}$, showed $61.6 \%$ hatching success, and those that reached $36.3^{\circ} \mathrm{C}$ (with the last $10 \mathrm{~d}$ of incubation $>35.5^{\circ} \mathrm{C}$ ) showed a $54.2 \%$ hatching success at a mean temperature of $31.6^{\circ} \mathrm{C}$ (Maulany et al. 2012a). However, the hatchlings that emerged from nests that reached temperatures $>34^{\circ} \mathrm{C}$ for at least $3 \mathrm{~d}$ showed a reduction in locomotor performance, suggesting that high incubation temperatures had sublethal effects (Maulany et al. 2012a). Other authors have also suggested that earlier embryonic stages may be more sensitive to high temperatures (e.g. Birchard 2004). It is likely that high temperatures have the largest effect on sea turtle embryos during the first 2 trimesters of development, although this requires further experimentation.

\section{INFLUENTIAL LITERATURE REVIEWS ON HIGH-TEMPERATURE INCUBATION}

Three early reviews of the embryology of sea turtles summarise the optimal incubation temperatures or maximum thermal limits of sea turtle eggs (Miller 1985, 1997, Ackerman 1997). These studies each focused on different aspects of the thermal environment, leading to very different conclusions. For example, Miller (1985, p. 272) concludes that 'Under natal beach conditions, the eggs incubate at temperatures between $24^{\circ}$ and $33^{\circ} \mathrm{C}^{\prime}$, whereas Ackerman (1997, p. 85) concludes that 'The thermal tolerance range (TTR) for development of sea turtle embryos incubated at constant temperature appears to fall between about 25 to $27^{\circ} \mathrm{C}$ and $33^{\circ}$ to $35^{\circ} \mathrm{C}$...'

Miller (1985) explicitly refers to natural incubation conditions in the field and (potentially) to the temperature range at which hatching success is optimal, by citing studies demonstrating successful embryonic development at temperatures above $33^{\circ} \mathrm{C}$, with a maximum of 35 to $37^{\circ} \mathrm{C}$ reached during late incubation (i.e. Hendrickson 1958, Caldwell 1959, Bustard 1972). Later, however, Miller (1997, p. 67) also states that 'eggs held at temperatures greater than $33^{\circ} \mathrm{C}$ for extended periods do not hatch', which some authors have interpreted as the putative upper thermal limit to embryonic development (Table 2). Ackerman (1997) specifically refers to the temperatures that embryos can physiologically tolerate, and thus provides a higher value of $35^{\circ} \mathrm{C}$ (note, however, that the minimum temperature provided by Ackerman [1997] is a degree higher than that provided by Miller
[1985]). Ackerman (1997) references Ewert (1985), who in turn references Bustard's (1971) study reporting that green turtle eggs can tolerate temperatures up to $35^{\circ} \mathrm{C}$ (Table 1 ).

Our review of the literature found that many subsequent studies cite Ackerman (1997) and Miller (1985 and/or 1997) interchangeably, or have taken some of their conclusions out of context (e.g. Table 2). Miller (1985) explicitly refers to natal beach conditions rather than lethal limits, which does not imply that $33^{\circ} \mathrm{C}$ is fatal for sea turtle embryos, but only that many nesting beaches do not reach this temperature (Table 1). Under climate change, natal beach conditions are likely to become warmer, and thus Ackerman's (1997) review of the absolute physiological tolerances of developing embryos is the more relevant early review, compared to the description of the range of natural incubation conditions provided by Miller (1985) (Table 2).

\section{SYNTHESIS OF HIGH-TEMPERATURE INCUBATION STUDIES}

Several studies have reported hatchlings successfully emerging from sea turtle eggs incubated at mean temperatures $>30^{\circ} \mathrm{C}$ (Table 1, Fig. 1). Hatching success declines substantially as the mean incubation temperature exceeds $29^{\circ} \mathrm{C}$ (Fig. 1). The highest recorded mean incubation temperature that resulted in hatchlings being produced is $35^{\circ} \mathrm{C}$, from green turtles (Fig. 1). Experiments on loggerhead turtle eggs incubated at 35 and $36^{\circ} \mathrm{C}$, and green turtle eggs incubated at $38^{\circ} \mathrm{C}$, did not produce any hatchlings (Table 1, Fig. 1). The limited data available suggest that leatherback and olive ridley embryos could have lower thermal tolerances than green and loggerhead turtles (Fig. 1), but this warrants further testing. Importantly, data on high-incubation temperatures and resultant hatching success are lacking for flatback turtles Natator depressus, hawksbill turtles, and Kemp's ridley turtles Lepidochelys kempii, which limit the generalisations that can be made about all sea turtle species (Table 1, Fig. 1).

\section{METABOLIC HEATING AND NEST TEMPERATURES}

When sea turtle embryos are developing rapidly during the period of internal organ differentiation, metabolic heat is produced and transferred to the nest chamber (Hendrickson 1958). The nest cham- 
Table 2. Example of oversimplified statements about the thermal tolerance of sea turtle eggs from seminal papers, based upon information available at the time of publication. C. caretta: Caretta caretta

\begin{tabular}{|c|c|c|}
\hline Reference & Statement about thermal tolerance & Discrepancy with primary literature \\
\hline Miller (1997, p. 67) & $\begin{array}{l}\text { '...eggs held at temperatures greater } \\
\text { than } 33^{\circ} \mathrm{C} \text { for extended periods do } \\
\text { not hatch.' }\end{array}$ & $\begin{array}{l}\text { Bustard (1971) found that eggs can hatch at } 35^{\circ} \mathrm{C} \text {. } \\
\text { Ackerman (1997, p. 85) states that 'The thermal tolerance } \\
\text { range (TTR) for development of sea turtle embryos } \\
\text { incubated at constant temperature appears to fall } \\
\text { between about } 25 \text { to } 27^{\circ} \mathrm{C} \text { and } 25 \text { to } 35^{\circ} \mathrm{C} . . .\end{array}$ \\
\hline $\begin{array}{l}\text { Hewavisenthi \& } \\
\text { Parmenter } \\
\text { (2002, p. 307) }\end{array}$ & $\begin{array}{l}\text { Paper cites Miller (1985) as evidence } \\
\text { that } 33^{\circ} \mathrm{C} \text { is the 'upper tolerance limit'. }\end{array}$ & $\begin{array}{l}\text { Miller }(1985, \text { p. } 272) \text { states that 'Under natal beach } \\
\text { conditions, the eggs incubate at temperatures between } \\
24-33^{\circ} \mathrm{C} . \text { ' There is no specific mention of an upper limit. }\end{array}$ \\
\hline $\begin{array}{l}\text { Miller et al. } \\
\qquad(2003, \text { p. 136) }\end{array}$ & $\begin{array}{l}\text { 'The maximum temperature for success- } \\
\text { ful incubation is } 33^{\circ} \mathrm{C} \text { [for C. caretta] in } \\
\text { eastern Australia (Limpus et al. 1985)'. }\end{array}$ & $\begin{array}{l}\text { Limpus et al. (1985) incubated eggs between } 25 \text { and } \\
32^{\circ} \mathrm{C} \text { and made no mention of } 33^{\circ} \mathrm{C} \text {. In addition, Limpus } \\
\text { et al. (1985) state that incubation above } 31^{\circ} \mathrm{C} \text { is the lethal } \\
\text { limit and reference Limpus et al. (1983), who incubated } \\
\text { eggs at temperatures up to } 32^{\circ} \mathrm{C} \text {, but refer to unpublished } \\
\text { data for an upper lethal limit of } 34^{\circ} \mathrm{C} \text {. }\end{array}$ \\
\hline $\begin{array}{l}\text { Hamann et al. } \\
\qquad(2007, \text { p. } 480)\end{array}$ & $\begin{array}{l}33^{\circ} \mathrm{C} \text { is 'near the upper limits for } \\
\text { incubation survival' (Miller 1997). }\end{array}$ & $\begin{array}{l}\text { Miller (1997) states that 'Under natal beach conditions, } \\
\text { the eggs incubate at temperatures between } 24-33^{\circ} \mathrm{C} . \text { ' } \\
\text { There is no mention of an upper limit. }\end{array}$ \\
\hline $\begin{array}{l}\text { Dobbs et al. } \\
\qquad(2010, \text { p. } 14)\end{array}$ & $\begin{array}{l}\text { Paper cites Miller (1985) as evidence } \\
\text { for '.... lethal threshold of incubation } \\
\text { temperature at approximately } 34^{\circ} \mathrm{C} . . .\end{array}$ & $\begin{array}{l}\text { Miller (1985) states that 'Under natal beach conditions, } \\
\text { the eggs incubate at temperatures between } 24-33^{\circ} \mathrm{C} . \text { ' } \\
\text { There is no mention of an upper limit. }\end{array}$ \\
\hline $\begin{array}{l}\text { Fuentes et al. } \\
\qquad(2012, \text { p. 58) }\end{array}$ & $\begin{array}{l}\text { Paper cites Miller (1985) as evidence for } \\
34^{\circ} \mathrm{C} \text { as the 'upper thermal threshold'. }\end{array}$ & $\begin{array}{l}\text { Miller (1985) states that 'Under natal beach conditions, } \\
\text { the eggs incubate at temperatures between } 24-33^{\circ} \mathrm{C} . \text { ' } \\
\text { There is no mention of an upper limit. }\end{array}$ \\
\hline $\begin{array}{l}\text { Maulany et al. } \\
\text { (2012a, p. 2658) }\end{array}$ & $\begin{array}{l}\text { 'Continuous incubation of sea turtle } \\
\text { eggs at temperatures above } 34^{\circ} \mathrm{C} \text { is } \\
\text { fatal (Miller 1997).' }\end{array}$ & $\begin{array}{l}\text { Miller (1997, p. 67) states that 'eggs held at temperature } \\
\text { greater than } 33^{\circ} \mathrm{C} \text { for extended periods do not hatch'. } \\
\text { Bustard (1971) found that eggs can hatch at } 35^{\circ} \mathrm{C} \text {. }\end{array}$ \\
\hline
\end{tabular}

ber often retains this heat (Wallace et al. 2004), which can increase nest temperatures above that of the surrounding substrate (Table 3). The extent of metabolic heating can also vary by position within the clutch (Standora et al. 1982). Metabolic heating mainly occurs during the latter third of incubation (Table 3), when embryos may be less susceptible to negative effects caused by exposure to high temperatures (e.g. as hypothesised by Birchard 2004). In the context of climate change, metabolic heating may have the most influence when nest temperatures are near the pivotal sex-determining temperature or near $35^{\circ} \mathrm{C}$, and at risk of exceeding lethal levels. Examples of vulnerable beaches include Ostional Beach, Costa Rica (Valverde et al. 2010); Senri Beach, Japan (Matsuzawa et al. 2002); Wembrak Beach, Indonesia (Tapilatu \& Tiwari 2007); and Alas Purwo National Park, Indonesia (Maulany et al. 2012b). In these cases, metabolic heating may drive nest temperatures to lethal limits, or at least high enough to cause sublethal effects (e.g. reduced locomotor ability).

The susceptibility of sea turtles eggs to lethal temperatures may depend on the species, and even on differences within species in terms of egg and clutch sizes. Smaller clutches, which have a higher surface area to mass ratio, may be able to more readily release metabolic heat to the surrounding environment, and thus experience lower core temperatures when compared to larger egg clutches (Hendrickson 1958, Hewavisenthi \& Parmenter 2002). Likewise, greater metabolic heating has been demonstrated in nests with a larger clutch mass in green turtles (Booth \& Astill 2001). Sea turtles with smaller clutch sizes (e.g. leatherback and flatback turtles; Van Buskirk \& Crowder 1994) may be least likely to reach lethal thermal limits if excess heat is lost to surrounding sand. These 2 species also produce the largest eggs (Miller 1985), which can improve hatching success, presumably by reducing water loss during incubation (Gutzke \& Packard 1985). However, increased egg size may also correlate with increased metabolic heating, causing Booth \& Astill (2001, p. 79) to note that 'the total amount of metabolic heat produced by a clutch will depend on the biomass of embryos within the clutch and this is a function of the egg size and number of eggs in the clutch.' Therefore, a smaller clutch may only release more metabolic heat 
Table 3. Summary of the effects of metabolic heating on sea turtle nest temperatures, shown for each third of the incubation period. In cases where standard deviations were presented in the text we converted them to standard errors for consistency

\begin{tabular}{|c|c|c|c|c|}
\hline \multirow[t]{2}{*}{ Species } & \multicolumn{3}{|c|}{ Metabolic heating $\left({ }^{\circ} \mathrm{C}, \pm \mathrm{SE}\right)$ by incubation stage } & \multirow[t]{2}{*}{ Reference } \\
\hline & First third & Middle third & Last third & \\
\hline \multirow[t]{4}{*}{ Caretta caretta } & $-0.6 \pm 0.10$ & $0.2 \pm 0.2$ & $1.64 \pm 0.56$ & Zbinden et al. (2006) \\
\hline & $0.1 \pm 0.1$ & $0.2 \pm 0.1$ & $0.9 \pm 0.1$ & Godley et al. (2001) \\
\hline & - & $\sim 0.6-0.7$ & $2.5-3.5$ & Maloney et al. (1990) \\
\hline & - & - & 3.0 & Maxwell et al. (1988) \\
\hline \multirow[t]{8}{*}{ Chelonia mydas } & - & - & $2.0-4.0$ & Booth \& Freeman (2006) \\
\hline & $\sim 0.1$ & $0.68-1.27$ & $3.0-4.0$ & Broderick et al. (2001) \\
\hline & $\sim 0.3$ & $\sim 0.3-1.2$ & $\sim 1.6-2.3$ & Carr \& Hirth (1961) \\
\hline & - & - & $3.0-5.0$ & Booth \& Astill (2001) \\
\hline & $\sim 0.1$ & $\sim 1.5-3$ & $\sim 5.0$ & Bustard (1972) \\
\hline & - & - & 6.0 & Standora et al. (1982) \\
\hline & - & - & $5.0-6.0$ & Bustard \& Greenham (1968) \\
\hline & - & - & 6.0 & Hendrickson (1958) \\
\hline \multirow[t]{2}{*}{ Dermochelys coriacea } & - & - & $4.0-8.0$ & Binckley et al. (1998) \\
\hline & $\sim 0.5$ & $\sim 0.8$ & $0.82 \pm 0.09$ & Godfrey et al. (1997) \\
\hline \multirow[t]{2}{*}{ Eretmochelys imbricata } & - & 1.1 & 3.4 & Glen \& Mrosovsky (2004) \\
\hline & - & - & $\sim 5.0$ & Raj (1976) \\
\hline Natator depressus & - & - & 0.5 & Hewavisenthi \& Parmenter (2002) \\
\hline
\end{tabular}

if the eggs themselves are also small. The literature for sea turtles on the effects of egg size on metabolic heating is limited, however (e.g. Table 3), and thus this topic requires further investigation.

\section{POTENTIAL OF TURTLES TO ADAPT TO INCREASING NEST TEMPERATURES}

The ability of sea turtles to cope with contemporary climate change will depend on their adaptability to increasing temperatures, which could include changes in phenology (Weishampel et al. 2004, Pike et al. 2006, Telemeco et al. 2013b), changes in nesting beach or nest-site choice (Weber et al. 2012), latitudinal advantages (Hawkes et al. 2007, Pike 2014), and, potentially, the thermoregulation of individual embryos inside of the egg (as has been documented in Chinese pond turtles Chinemys reevesii; Zhao et al. 2013). The pace at which contemporary climate change is occurring could be more rapid than the adaptation of sea turtles to such change (Hamann et al. 2013). For instance, the timing of breeding is often affected by the climatic conditions at feeding sites, which can be more than a thousand kilometres from nesting rookeries (Plotkin 2003, Polovina et al. 2004). Any phenological shifts in the timing of nesting for a whole population could therefore take generations (Hamann et al. 2007). However, changes in phenology over much shorter time periods have already been reported, with sea turtle populations nesting earlier when ocean temperatures are warmer (reviewed by Hamann et al. 2013).

Recent evidence suggests that some sea turtle populations could be adapted to warmer local incubation environments than other populations. On Ascension Island, green turtle nests incubating within the warmer black sands survive better at hotter incubation temperatures then those laid in cooler pale sands (Weber et al. 2012). Even if sea turtles begin selecting beaches which provide cooler nest temperatures (e.g. as a result of the sand colour, grain size, beach orientation, canopy shading, etc.; Ackerman 1997, Moran et al. 1999, Booth \& Freeman 2006, Poloczanska et al. 2009), the pace of adaptation may be unable to keep up with current levels of rapid warming. Sea turtle populations at higher latitudes, however, may fare better than those at lower, tropical latitudes, because the temperatures at high latitudes may become more favourable as temperatures increase, whereas those in tropical locations may exceed lethal levels (Hawkes et al. 2009, Pike 2014).

Human management interventions may possibly help sea turtles adapt to climate change (reviewed by Fuentes et al. 2012). First and foremost, reducing anthropogenic threats is necessary to provide sea turtles the best opportunity for survival during contemporary climate change. Protecting incubating eggs from lethally high temperatures, and ensuring the production of male offspring, are important secondary goals (Fuentes et al. 2012). Measures which will help achieve these goals include manipulating vegetation 
cover to alter nest temperature, artificially incubating eggs at desired temperatures, adding sand of different thermal properties, cooling the sand using sprinklers, and protecting natural beach features by limiting human development (Fuentes et al. 2012). Nearly all of these strategies could be effective in some instances, but identifying the underlying climate change threat to individual nesting beaches is key to selecting the most appropriate strategy (Fuentes et al. 2012).

\section{CONCLUSIONS AND FUTURE DIRECTIONS}

Observational field studies and laboratory experiments have contributed useful information to understanding the relationship between hatching success of sea turtle embryos and temperature. Existing data reveal strong differences in lethal temperature thresholds within and among populations, depending (at least partially) on turtle species, geographic location, environmental temperatures, and nest depth (Table 1, Fig. 1). The lethal limit or threshold temperature for sea turtle embryos is usually cited as ranging between 33 and $35^{\circ} \mathrm{C}$, with both Miller (1997) and Ackerman (1997) as common references. However, it is much less commonly acknowledged that embryos can and do survive temperatures above these limits. Overall, developing sea turtle embryos rarely hatch when the mean incubation temperature is $35^{\circ} \mathrm{C}$, and, when embryos survive temperatures 1 to $2^{\circ} \mathrm{C}$ above this, hatchlings are only produced when these high temperatures are reached during the latter part of incubation. The exact lethal limit of sea turtles will most likely never be known, unlike the sex-determining temperature, given that it is not just the temperature but also the duration at that temperature which dictates hatching success (Valverde et al. 2010). Nevertheless, more accurate data on each species and their respective nesting beaches are required to make meaningful predictions of hatching success under climate change. Because experiencing optimal incubation temperatures is fundamental to successful embryonic development (Hamann et al. 2007), and high temperatures are predicted to have the greatest effect on sea turtle nesting as a result of climate change (Fuentes et al. 2011), knowledge of these processes and the effects of climate change require more fundamental research.

Given the rapidly growing literature on climate change in sea turtles (reviewed by Hawkes et al. 2009), it is surprising that more research has not been done on the effects of temperature on embryonic developmental limits. Many researchers are hesitant to conduct potentially lethal experiments on eggs of species of conservation concern; however, with the increasing population trends of many rookeries worldwide this may begin to change. Collecting a few hundred eggs for experiments that could substantially advance our ability to forecast the spatial and temporal impacts of climate change, and better understand the risks of negative impacts on populations and species is certainly justified because the knowledge benefits (when shared with the scientific community) likely outweigh any potential demographic effects to individual nesting beaches.

Experimental studies that use artificial incubators to mimic realistic nest temperatures can be used to tackle much more complicated questions about sea turtle embryology (Bowden et al. in press), but have some disadvantages because these experiments are unable to imitate natural nest conditions and thus may be less accurate (Telemeco et al. 2013b). The use of constant temperature incubation experiments has also been questioned with respect to its effects on metabolic heating, and whether this would influence embryonic development (McGehee 1979). For sea turtles, natural fluctuations in nest temperatures and metabolic heating are generally quite predictable, especially when the nests are located deep underground, which may allow easier replication in the laboratory. Once physiological tolerances are known, other sources of temperature variation (e.g. effects of nest depth and intra-clutch thermal gradients) can be modelled. Far more difficult to replicate in the laboratory are the potentially important interactions between temperature and oxygen partial pressure in nests (which tend to drop more rapidly at higher temperatures), which could help us understand the physiological limits of embryonic development.

Many of the current knowledge gaps we highlight can be addressed by focusing on the factors that modulate the relationship between temperature and survival, rather than on attempting to generalise a lethal temperature for embryonic development. Experimentally defining temperature survival curves for individual species, and populations within species, will help determine the plasticity of this trait across the range of a species, and thus the potential for embryonic responses to climate change. Determining how heritable this variation is could lead to novel insights on population resilience. Understanding relationships between incubation temperature and oxygen tension within the nest could also provide important mechanistic insights into how temperature influences sea turtle embryonic development. Advancing our current state of knowledge of this 
topic will substantially improve our ability to understand the impacts of climate change on globally distributed marine megafauna that are entirely dependent upon coastal terrestrial environments for successful reproduction.

Acknowledgements. We thank the librarians at the University of New England for their diligence in tracking down an elusive copy of Jeffrey Miller's PhD thesis, a defining work on the incubation environment of sea turtle eggs. The late Raju Radder contributed to discussions on metabolic heating, and the thought-provoking comments from 4 reviewers greatly improved our manuscript. Support during manuscript preparation was provided by the School of Marine and Tropical Biology, James Cook University.

\section{LITERATURE CITED}

Ackerman RA (1997) The nest environment and the embryonic development of sea turtles. In: Lutz PL, Musick JA (eds) The Biology of Sea Turtles, Vol 1. CRC Press, Boca Raton, FL, p 83-106

Binckley CA, Spotila JR, Wilson KS, Paladino FV (1998) Sex determination and sex ratios of Pacific leatherback turtles, Dermochelys coriacea. Copeia 1998:291-300

Birchard GF (2004) Effects of incubation temperature. In: Deeming DC (ed) Reptilian incubation: environment, evolution and behaviour. Nottingham University Press, Nottingham, p 103-123

> Booth DT, Astill K (2001) Temperature variation within and between nests of the green sea turtle, Chelonia mydas (Chelonia: Cheloniidae) on Heron Island, Great Barrier Reef. Aust J Zool 49:71-84

Booth DT, Evans A (2011) Warm water and cool nests are best. How global warming might influence hatchling green turtle swimming performance. PLoS ONE 6: e23162

Booth DT, Freeman C (2006) Sand and nest temperatures and an estimate of hatchling sex ratio from the Heron Island green turtle (Chelonia mydas) rookery, Southern Great Barrier Reef. Coral Reefs 25:629-633

Booth DT, Feeney R, Shibata Y (2013) Nest and maternal origin can influence morphology and locomotor performance of hatchling green turtles (Chelonia mydas) incubated in field nests. Mar Biol 160:127-137

Bowden RM, Carter AW, Paitz RT (in press) Constancy in an inconstant world: moving beyond constant temperatures in the study of reptilian incubation. Integr Comp Biol

Broderick AC, Godley BJ, Hays GC (2001) Metabolic heating and the prediction of sex ratios for green turtles (Chelonia mydas). Physiol Biochem Zool 74:161-170

Bustard HR (1971) Temperature and water tolerances of incubating sea turtle eggs. Br J Herpetol 4:196-198

Bustard HR (1972) Sea turtles, their natural history and conservation. Collins, Sydney

Bustard HR, Greenham P (1968) Physical and chemical factors affecting hatching in the green sea turtle, Chelonia mydas (L.). Ecology 49:269-276

Caldwell DK (1959) The loggerhead turtles of Cape Romain, South Carolina. Bull Fla State Mus Biol Sci 4:319-348

> Carr A, Hirth H (1961) Social facilitation in green turtle hatchlings. Anim Behav 9:68-70
Deutsch CA, Tewksbury JJ, Huey RB, Sheldon KS, Ghalambor CK, Haak DC, Martin PR (2008) Impacts of climate warming on terrestrial ectotherms across latitude. Proc Natl Acad Sci USA 105:6668-6672

Dobbs KA, Miller JD, Limpus C, Landry AM Jr (2010) Hawksbill turtle hatchling sex ratios and incubation and pivotal temperatures from Milman Island, Great Barrier Reef, Australia. Mar Turtle Newsl 128:12-16

Doody JS, Moore JA (2010) Conceptual model for thermal limits on the distribution of reptiles. Herpetol Conserv Biol 5:283-289

> Drake DL, Spotila JR (2002) Thermal tolerances and the timing of sea turtle hatchling emergence. J Therm Biol 27: $71-81$

> Du WG, Ji X (2003) The effects of incubation thermal environments on size, locomotor performance and early growth of hatchling soft-shelled turtles, Pelodiscus sinensis. J Therm Biol 28:279-286

Ewert MA (1985) Embryology of turtles. In: Gans C, Billett F, Maderson PFA (eds) Biology of the Reptilia, Vol 14. Wiley, New York, NY, p 75-267

> Fuentes M, Hamann M, Limpus C (2010) Past, current and future thermal profiles of green turtle nesting grounds: implications from climate change. J Exp Mar Biol Ecol 383:56-64

Fuentes M, Limpus C, Hamann M (2011) Vulnerability of sea turtle nesting grounds to climate change. Glob Change Biol 17:140-153

Fuentes M, Fish M, Maynard J (2012) Management strategies to mitigate the impacts of climate change on sea turtle's terrestrial reproductive phase. Mitig Adapt Strategies Glob Change 17:51-63

Glen F, Mrosovsky N (2004) Antigua revisited: the impact of climate change on sand and nest temperatures at a hawksbill turtle (Eretmochelys imbricata) nesting beach. Glob Change Biol 10:2036-2045

> Godfrey MH, Barreto R, Mrosovsky N (1997) Metabolicallygenerated heat of developing eggs and its potential effect on sex ratio of sea turtle hatchlings. J Herpetol 31: 616-619

Godley B, Broderick A, Downi J, Glen F and others (2001) Thermal conditions in nests of loggerhead turtles: further evidence suggesting female skewed sex ratios of hatchling production in the Mediterranean. J Exp Mar Biol Ecol 263:45-63

Gutzke WH, Packard GC (1985) Hatching success in relation to egg size in painted turtles (Chrysemys picta). Can J Zool 63:67-70

Hamann M, Limpus CJ, Read MA (2007) Vulnerability of marine reptiles in the Great Barrier Reef to climate change. In: Johnson JE, Marshall PA (eds) Climate change and the Great Barrier Reef. Great Barrier Reef Marine Park Authority and Australian Greenhouse Office, Brisbane

Hamann M, Fuentes M, Ban N, Mocellin V (2013) Climate change and marine turtles. In: Wyneken J, Lohmann KJ, Musick JA (eds) The biology of sea turtles, Vol 3. Taylor and Francis Group, Boca Raton, FL, p 353-378

Hawkes L, Broderick A, Godfrey M, Godley B (2007) Investigating the potential impacts of climate change on a marine turtle population. Glob Change Biol 13:923-932

Hawkes LA, Broderick AC, Godfrey MH, Godley BJ (2009) Climate change and marine turtles. Endang Species Res $7: 137-154$

> Hendrickson JR (1958) The green sea turtle, Chelonia 
mydas (Linn.) in Malaya and Sarawak. J Zool (Lond) 130: 455-535

> Hewavisenthi S, Parmenter CJ (2002) Incubation environment and nest success of the flatback turtle (Natator depressus) from a natural nesting beach. Copeia 2002: 302-312

Ischer T, Ireland K, Booth DT (2009) Locomotion performance of green turtle hatchlings from the Heron Island rookery, Great Barrier Reef. Mar Biol 156:1399-1409

James MC, Davenport J, Hays GC (2006) Expanded thermal niche for a diving vertebrate: a leatherback turtle diving into near-freezing water. J Exp Mar Biol Ecol 335: 221-226

> Jourdan J, Fuentes M (in press) Effectiveness of strategies at reducing sand temperature to mitigate potential impacts from changes in environmental temperature on sea turtle reproductive output. Mitig Adapt Strategies Glob Change, doi 10.1007/s11027-013-9482-y

Laloë JO, Cozens J, Renom B, Tazonera A, Hays GC (2014) Effects of rising temperature on the viability of an important sea turtle rookery. Nat Clim Change 4:513-518

Limpus C, Reed P, Miller J (1983) Islands and turtles. The influence of choice of nesting beach on sex ratio. In: Baker JT, Carter RM, Sammarco PW, Stark KP (eds) Proceedings of the inaugural Great Barrier Reef conference. James Cook University Press of North Queensland, Townsville, p 397-402

Limpus CJ, Reed PC, Miller JD (1985) Temperature dependent sex determination in Queensland sea turtles: intraspecific variation in Caretta caretta. In: Shine R, Ehmann H, Grigg G (eds) Biology of Australasian frogs and reptiles. Surrey Beatty and Sons, Sydney, p 343-351

- Maloney JE, Darian-Smith C, Takahashi Y, Limpus CJ (1990) The environment for development of the embryonic loggerhead turtle (Caretta caretta) in Queensland. Copeia 1990:378-387

- Matsuzawa Y, Sato K, Sakamoto W, Bjorndal K (2002) Seasonal fluctuations in sand temperature: effects on the incubation period and mortality of loggerhead sea turtle (Caretta caretta) pre-emergent hatchlings in Minabe, Japan. Mar Biol 140:639-646

Maulany R, Booth D, Baxter G (2012a) The effect of incubation temperature on hatchling quality in the olive ridley turtle, Lepidochelys olivacea, from Alas Purwo National Park, East Java, Indonesia: implications for hatchery management. Mar Biol 159:2651-2661

Maulany R, Booth D, Baxter G (2012b) Emergence success and sex ratio of natural and relocated nests of olive ridley turtles from Alas Purwo National Park, East Java, Indonesia. Copeia 2012:738-747

Maxwell JA, Motara MA, Frank GH (1988) A microenvironmental study of the effect of temperature on the sex-ratios of the loggerhead turtle, Caretta caretta, from Tongaland, Natal. S Afr J Zool 23:342-350

McGehee MA (1979) Factors affecting the hatching success of loggerhead sea turtle eggs (Caretta caretta caretta). Master's thesis, University of Central Florida, Orlando, FL

Micheli-Campbell M, Gordos M, Campbell H, Booth D, Franklin C (2012) The influence of daily temperature fluctuations during incubation upon the phenotype of a freshwater turtle. J Zool (Lond) 288:143-150

Miller JD (1982) Embryology of marine turtles. PhD dissertation, University of New England, Armidale, NSW

Miller JD (1985) Embryology of marine turtles. In: Gans C,
Billett F, Maderson PFA (eds) Biology of the Reptilia, Vol 14A. Wiley-Interscience, New York, NY, p 269-328

Miller JD (1997) Reproduction in sea turtles. In: Lutz PL, Musick JA (eds) The biology of sea turtles. CRC Press, Boca Raton, FL, p 51-80

Miller J, Limpus C (1981) Incubation period and sexual differentiation in the green turtle Chelonia mydas L. In: Proceedings of the Melbourne Herpetological Symposium Zoological Board of Victoria, Parkville, p 66-73

Miller JD, Limpus CJ, Godfrey MH (2003) Nest site selection, oviposition, eggs, development, hatching, and emergence of loggerhead sea turtles. University Press of Florida, Gainesville, FL, p 125-143

Moran KL, Bjorndal KA, Bolten AB (1999) Effects of the thermal environment on the temporal pattern of emergence of hatchling loggerhead turtles Caretta caretta. Mar Ecol Prog Ser 189:251-261

> Mortimer JA (1990) The influence of beach sand characteristics on the nesting behavior and clutch survival of green turtles (Chelonia mydas). Copeia 1990:802-817

Mrosovsky N (1980) Thermal biology of sea turtles. Am Zool 20:531-547

Mrosovsky N (1994) Sex ratios of sea turtles. J Exp Zool 270: 16-27

Packard GC, Tracy CR, Roth JJ (1988) The physiological ecology of reptilian eggs and embryos. In: Gans C, Huey RB (eds) Biology of the Reptilia, Vol 16. Ecology. Alan R. Liss, New York, NY, p 523-605

Pike DA (2013) Climate influences the global distribution of sea turtle nesting. Glob Ecol Biogeogr 22:555-566

Pike DA (2014) Forecasting the viability of sea turtle eggs in a warming world. Glob Chang Biol 20:7-15

> Pike DA, Antworth RL, Stiner JC (2006) Earlier nesting contributes to shorter nesting seasons for the loggerhead seaturtle, Caretta caretta. J Herpetol 40:91-94

Plotkin P (2003) Adult migrations and habitat use. In: Lutz PL, Musick JA, Wyneken J (eds) The biology of sea turtles, Vol 2. CRC Press, Boca Raton, FL, p 225-242

Poloczanska ES, Limpus CJ, Hays GC (2009) Vulnerability of marine turtles to climate change. Adv Mar Biol 56: $151-211$

Polovina JJ, Balazs GH, Howell EA, Parker DM, Seki MP, Dutton PH (2004) Forage and migration habitat of loggerhead (Caretta caretta) and olive ridley (Lepidochelys olivacea) sea turtles in the central North Pacific Ocean. Fish Oceanogr 13:36-51

Raj U (1976) Incubation and hatching success in artificially incubated eggs of the hawksbill turtle, Eretmochelys imbricata (L.). J Exp Mar Biol Ecol 22:91-99

> Read T, Booth DT, Limpus CJ (2013) Effect of nest temperature on hatchling phenotype of loggerhead turtles (Caretta caretta) from two South Pacific rookeries, Mon Repos and La Roche Percée. Aust J Zool 60:402-411

Segura LN, Cajade R (2010) The effects of sand temperature on pre-emergent green sea turtle hatchlings. Herpetol Conserv Biol 5:196-206

Standora EA, Morreale SJ, Ruiz GJ, Spotila JR (1982) Sex determination in green turtle (Chelonia mydas) hatchlings can be influenced by egg position within the nest. Bull Ecol Soc Am 63:83-84

- Tapilatu RF, Tiwari M (2007) Leatherback turtle, Dermochelys coriacea, hatching success at Jamursba-Medi and Wermon beaches in Papua, Indonesia. Chelonian Conserv Biol 6:154-158

Telemeco RS, Warner DA, Reida MK, Janzen FJ (2013a) 
Extreme developmental temperatures result in morphological abnormalities in painted turtles (Chrysemys picta): a climate change perspective. Integr Zool 8: 197-208

Telemeco RS, Abbott KC, Janzen FJ (2013b) Modeling the effects of climate change-induced shifts in reproductive phenology on temperature-dependent traits. Am Nat 181:637-648

Valverde RA, Wingard S, Gómez F, Tordoir MT, Orrego CM (2010) Field lethal incubation temperature of olive ridley sea turtle Lepidochelys olivacea embryos at a mass nesting rookery. Endang Species Res 12:77-86

Van Buskirk J, Crowder LB (1994) Life-history variation in marine turtles. Copeia 1994:66-81

> Wallace BP, Sotherland PR, Spotila JR, Reina RD, Franks BF, Paladino FV (2004) Biotic and abiotic factors affect the nest environment of embryonic leatherback turtles, Dermochelys coriacea. Physiol Biochem Zool 77:423-432

Weber SB, Broderick AC, Groothuis TG, Ellick J, Godley BJ, Blount JD (2012) Fine-scale thermal adaptation in a green turtle nesting population. Proc Biol Sci 279:1077-1084

Weishampel JF, Bagley DA, Ehrhart LM (2004) Earlier nesting by loggerhead sea turtles following sea surface warming. Glob Change Biol 10:1424-1427

Editorial responsibility: Matthew Godfrey, Beaufort, North Carolina, USA
Wibbels T (2003) Critical approaches to sex determination in sea turtles. In: Lutz PL, Musick JA, Wyneken J (eds) The biology of sea turtles, Vol 2. CRC Press, Boca Raton, FL, p 103-134

Witt MJ, Hawkes LA, Godfrey MH, Godley BJ, Broderick AC (2010) Predicting the impacts of climate change on a globally distributed species: the case of the loggerhead turtle. J Exp Biol 213:901-911

Wood A, Booth DT, Limpus CJ (2014) Sun exposure, nest temperature and loggerhead turtle hatchlings: implications for beach shading management strategies at sea turtle rookeries. J Exp Mar Biol Ecol 451:105-114

Yntema C, Mrosovsky N (1980) Sexual differentiation in hatchling loggerheads (Caretta caretta) incubated at different controlled temperatures. Herpetologica 36:33-36

Yntema C, Mrosovsky N (1982) Critical periods and pivotal temperatures for sexual differentiation in loggerhead sea turtles. Can J Zool 60:1012-1016

Zbinden JA, Margaritoulis D, Arlettaz R (2006) Metabolic heating in Mediterranean loggerhead sea turtle clutches. J Exp Mar Biol Ecol 334:151-157

> Zhao B, Li T, Shine R, Du WG (2013) Turtle embryos move to optimal thermal environments within the egg. Biol Lett 9: 20130337

Submitted: May 20, 2014; Accepted: July 18, 2014

Proofs received from author(s): October 11, 2014 